\title{
PLACING BUSINESS ETHICS IN CONTEXTUAL THEOLOGICAL EDUCATION
}

\author{
Yahya Wijaya \\ Duta Wacana Christian University
}

\section{Abstract}

This study focuses on the relevance of business ethics for contextual theological education in Asia particularly with the background of Protestant traditions. There are professional reasons why business ethics could be worth offering to students who are in preparation to become pastors and prospective church leaders as well as those who are already in those positions. With an area of theological study, such as biblical studies, systematic theology, practical theology, or contextual theology and religious studies, selected as entry point, business ethics learning could be fittingly placed in theological education. Ethical issues which have been widely discussed both in the theological forum and that of business studies are worth developing as key topics of theological business ethics.

\section{Key words}

Theological business ethics, contextual theology, economic theology, pastoral ministry, theological education

Few business schools in Asia have offered business ethics as a single course although business ethical premises are implied in courses such as professionalism, corporate social responsibility, and Islamic economics. It is therefore not surprising that business ethics is rarely thought of in other academic fields like theological education. Although ethics or moral philosophy is an important subject in theological curricula, its nature as a theoretical course cannot accommodate the complexity of business moral issues, let alone in relation to practical theological concerns. Likewise, courses in applied theological ethics are 
usually more associated to either moral dilemma in the private life or social-political affairs. In that case, theological talks on business issues are usually nothing more than an insert of a discussion concerning larger social problems.

\section{Why business ethics?}

Business ethics can be defined as a part of economic ethics which focuses on micro and mezzo levels of economic life. ${ }^{1}$ In that sense, business ethics covers a broad range of moral concern involving business institutions and business-related organizations as well as individual business actors. The increasing role played by the private sector in almost all areas of life; large-scale corruption involving top level executives in major corporations such as Enron, WorldCom, and Parmalat; the collapse of many Asian financial enterprises in late 1990s leading to the region's severe economic crisis; and the evidence of environmental disorder related to the ethical negligence of business operations: all have triggered the recent awareness of the importance of business ethics. ${ }^{2}$ The idea of business ethics rests on the belief that business cannot be considered as simply a tool of economic interests. Business ethics reveals the ethical dimension of business which is no less crucial than the economic one and, therefore, worth taking care of in order for the business practice to do good to all stakeholders.

As far as ethics is concerned, theology is a valuable resource. Christian theology, in particular, has been exercised as the main ethical reference for business activities including production, trade, and commerce since as early as the medieval era in the forms of the rule of the sixth century's Benedictine monasteries and the teaching of Thomas Aquinas. ${ }^{3}$ However, since the discipline of economics started to develop, much influenced by Adam Smith's philosophy of self-interest, the role of theology in business ethics has gradually diminished. ${ }^{4}$ Several theologians as well as economists today have shown concern about the uneasy relation of business ethics and theology. ${ }^{5}$ Promoting reconciliation between the two

\footnotetext{
${ }^{1}$ Christoph Stückelberger, 'Economic Ethics' in Helmut K. Anheier, Mark Juergensmeyer, and Victor Faessel, eds., Encyclopedia of Global Studies (Thousand Oaks, CA: SAGE, 2012),p. 450

${ }^{2}$ Christopher J. Cowton and Michaela Haase, Trends in Business and Economic Ethics (Berlin/Heidelberg: SpringerVerlag, 2008), p. 1

${ }^{3}$ Oliver F. Williams, 'Introduction' in Oliver F. Williams, ed., Business, Religion, and Spirituality: A New Synthesis (Notre Dame, Indiana: University of Notre Dame Press, 2003) pp.1-28 at pp. 2-3

${ }^{4}$ Richard Higginson, Questions of Business Life: Exploring Workplace Issues from a Christian Perspective (Carlisle, Cumbria: Spring Harvest, 2002), p. 11

${ }^{5}$ See, for instance: Andy Hartropp, 'Why is Engagement between Christian Economists and Theologians Difficult?' in Jeremy Kidwell and Sean Doherty, eds., Theology and Economics: A Christian Vision of the Common Good. (New York, NY: Palgrave Macmillan, 2015), pp. 11-26
} 
fields, the economists call theologians to update their knowledge concerning market vision and factual economic achievements, whilst the theologians suggest the economists to revisit theological resources and recognize their relevance for the increasing awareness of the spiritual dimension of business.

Such a call for reconciliation between theology and business ethics, however, has not yet responded adequately in Asia. Although theologians from the mainstream Protestant and Roman Catholic traditions in Asia commonly welcome, and many have even enthusiastically employed, the contextual theological approach, few have understood the business world as an important context worth reflecting theologically. In term of the economy, Asian contextual theology tends to focus more on the macro level, namely the issues regarding economic system and structure, whilst business ethics, which is situated in the mezzo and micro levels, is almost neglected. ${ }^{6}$

The ignorance of Asian contextual theologians to business ethics is in fact inconsistent with the mission of contextual theology to pay serious attention and apply appreciative approach to the local context. Any understanding of the context of Asia will not be sufficient without paying attention to the Asian business sphere with its own characteristics and complexities. Asia has become the continent where centres of international trade situated at least since the time of the famous silk route. Today, Asia is the basis of many of the most dynamic markets in the world, and its contribution to the growth of the global economy is increasing year by year. Oxford Economics forecasts that Asia's share in the global economy will be approaching $45 \%$ in $2025 .^{7}$ With such a remarkable economic performance, Asia is undoubtedly conducive for the formation and expansion of corporations of large, medium, and small scales. That business feature of the Asian context deserves ethical response which is accountable both theologically and economically. According to a survey result conducted by Laura Nash, one factor affecting the ignorance of business by theologians and pastoral staff is the absence of courses on business in theological curricula. ${ }^{8}$ That is the main reason why business ethics teaching should be accommodated in Asian theological education which claims to be contextual. Additionally, there are practical reasons.

Firstly, quite a number of theological students, particularly in the postgraduate level, are pastors serving congregations with business actors in the membership and even leadership. In such congregations,

\footnotetext{
${ }^{6}$ See: Yahya Wijaya, 'Economic Globalization and Asian Contextual Theology' Theological Studies, 69 (2008), 309-320 at 314

7 Akrur Barua, 'Packing a Mightier Punch: Asia's Economic Growth among Global Markets Continues' Asia Pacific Economic Outlook, Q1, 2016 <http:dupress.deloitte.com/dup-us-en/economy/asia-pacific-economicoutlook/2016/q1-asia-economic-growth-continues.html\#> [ accessed 04/10/2016]

${ }^{8}$ Laura L. Nash, 'A Spiritual Audit of Business: From Tipping Point to Tripping Point' in Oliver F. Williams, ed., Business, Religion, and Spirituality: A New Synthesis (Notre Dame, Indiana: University of Notre Dame Press, 2003), pp. 53-79 at p. 61
} 
pastoral consultations are often concerning ethical enquiries and moral dilemma which the church members face in their business activities. Lacking knowledge in business ethics, a pastor often fails to provide a contextual pastoral service, and rather tends to offer either a dogmatic, utopian view or a pragmatic one. As Laura Nash observes, "[f]or many theologians and members of the clergy, business simply does not compute as legitimate focus of religious expression." 9 Secondly, the awakening of the so called Islamic economy has stimulated Christian business actors to wonder whether Christianity could equally offer a faith-based concept of economy implying business practices which can be confirmed to be consistent to the Christian faith. In this case, Christian business actors often have questions about how and to what extent they should involve with a business partner practising Islamic economy. A pastoral response to such query should have a strong reference in business ethical perspectives. A response based merely on theology or economics could be irrelevant or trivial. Thirdly, there is no area of societal life, including religion, which is not affected by business. In fact, business plays a crucial role in providing goods and services needed in every societal event and institution including religious ones. Churches and churchrelated institutions are among those taking the advantage of the financial market in managing their endowment funds. In other words, the church itself to some extent is a business player, as Mara Einstein has explored. ${ }^{10}$ In such a position, the challenge for the church is how to be a sample of those doing business responsibly. Theologians, as the church's intellectuals, cannot escape from the task of equipping the church ethically not only in doing its conventional works, but also in the business dimension of its management.

\section{Entry Points}

In offering business ethics to theological students, it is important to find fitting entry points so as to show the proper place of business ethics in the curriculum. The standard curriculum in an Asian theological school or seminary with a Protestant tradition background can normally be divided into four main areas: biblical studies, systematic and historical theology, practical theology, as well as contextual theology and religious studies.

Biblical Studies

\footnotetext{
${ }^{9}$ Ibid, p. 60
}

${ }^{10}$ Mara Einstein, Brands of Faith: Marketing Religion in a Commercial Age. (London/NY: Routledge, 2008) 
Although the Bible uses many depictions and terms drawn from the economic field, such as the parable of the landowner who planted a vineyard (Mt. 21:33-46), the parable of the servants (Mt. 25:14-30), and the parable of the dishonest manager (Lk. 16:1-13), their original meaning may not be primarily about actual business practices. Those parables are rather used as illustrations for the teaching about the Kingdom of God with its spiritual and ethical consequences. To be sure, the concept of the Kingdom of God has implications in all areas of life including economic one, but a direct application of those stories to the contemporary situation would not meet their true messages. Even seemingly explicit biblical references to a particular business situation, such as the rule of the jubilee year (Deut 15:1-11), may reflect a particular economic system which is extremely different in many aspects from modern economy. As Ronald Preston has suggested, using the Bible as a straightforward reference for dealing with contemporary moral issues would not be responsible both to the actual context and to the Bible itself. ${ }^{11}$ Biblical studies are the academic attempt to make the Bible relevant for today's situation through the process of hermeneutics which includes on the one hand, interplaying critical interpretations of the biblical accounts and, on the other hand, analysis of the current situation which may need to borrow data and methods from nontheological disciplines, including economics.

One example of doing biblical hermeneutics for the purpose of business ethics teaching is what has been attempted by Sigmund Wagner-Tsukamoto. ${ }^{12}$ Concentrating on the Old Testament stories of Joseph and those of Solomon, Wagner-Tsukamoto argues that those biblical stories give pictures of economically as well as ethically successful leadership and management which are relevant for today's business institution. For Wagner-Tsukamoto, both Joseph and Solomon demonstrate leadership and management characterized by five principles: committed to public good, generating law-abiding behaviour, striving for mutual gains, encouraging ethical capital creation, and welcoming pluralism of the people's value system.

\section{Systematic and Historical Theology}

The area of systematic and historical theology consists of courses in Christian doctrines, church history, and ethics. Richard Higginson ${ }^{13}$ has attempted to offer business ethics learning drawn from the structure of Christian doctrines. He relates basic Christian doctrines including the Trinity, creation, resurrection, and the

\footnotetext{
${ }^{11}$ Ronald Preston, Religion and the Ambiguities of Capitalism (Cleveland, Ohio: The Pilgrim Press, 1993), pp. 96-109

12 Sigmund Wagner-Tsukamoto, 'Ethical Principles of Old Testament Economics: Implications for the Teaching of Business Ethics' Journal of Religion and Business, 3 (2014), art.16

${ }^{13}$ Richard Higginson, Called to Account: Adding Value in God's Word, Integrating Christianity and Business Effectively (Guildford: Eagle, 1993)
} 
Holy Spirit, to the business issues such as company community, wealth-creation, business and employment risk, as well as intercultural communication. Focusing on ethical issues in the mezzo level - the business institution, Higginson's work is not common in the theological arena and thus worth appraising as an important contribution. Yet, a more usual entry point to the teaching of business ethics in the area of systematic theology is the courses in ethics.

Theological courses in ethics normally comprise basic ethics and special ethics. Within the category of special ethics, a course in economic ethics is often included. However, theological perspectives on economic ethics studied in contextual theological education with mainstream Protestant background tend to be narrowly directed to macro-economic issues at the expense of the interests in mezzo and micro levels of economic life. Max Stackhouse ${ }^{14}$ argues that mainstream theologians should maintain their concern for social justice otherwise the existence of the mainstream Christian traditions would be at stake. What is misleading, according to Stackhouse, is the tendency of mainstream theologians to analyse social justice issues with the lens of outdated socialism. That tendency, he goes on to suggest, has made such theologians fail to recognise the real matters in today's economic life. Stackhouse calls for a "revitalisation" of Christian economic ethics by redirecting its priority to three crucial areas: "family and local community life, international corporate and commercial life, and high-tech electronic communications." ${ }^{15}$

In accord with Stackhouse, David Krueger ${ }^{16}$ suggests that Christian economic ethics should decelerate its enthusiasm in condemning the existing economic system, and instead pay more attention to the institutional and practical levels. Referring to H. R. Niebuhr's ethics of responsibility and his transformational type of theology-culture engagement, Krueger considers a confrontational approach against capitalism a form of 'Christ against culture' type which is unfitting. He recommends instead a transformational approach relating the idea of justice to productivity. By suggesting such an approach, Krueger is aware of the moral defects of the existing economy. Yet, he does not believe that a radical deconstruction would offer a better alternative. Krueger's ethics of productive justice concerns with the way business products affect consumers and society, the human rights, relevant institutions and communities, as well as the environment. ${ }^{17}$

\footnotetext{
${ }^{14}$ Max Stackhouse, 'Christian Social Ethics in a Global Era: Reforming Protestant View' in Max Stackhouse, ed., Christian Social Ethics in a Global Era (Nashville, TN: Abingdon Press, 1955).

15 Ibid, p.26

${ }^{16}$ David A. Krueger, The Business Corporation and Productive Justice (Nashville: Abingdon Press, 1997)

17 Ibid, p. 58
} 
In term of business ethics teaching, Deon Rossouw ${ }^{18}$ mentions three different purposes directed to different competencies: cognitive, behavioural, and managerial. As the position of a pastor in the business context is as caregiver rather than business practitioner, the type of business ethics education in a pastoral course should refer to the cognitive competency. According to Rossouw, the cognitive competency is about awareness, understanding, and reasoning of the moral dimension of business, as well as the complexity in moral decision making and the variety of moral perspectives requiring moral tolerance. Rossouw notes two dominant types of ethics employed in the cognitive competency-oriented education, namely deontology and utilitarianism. Yet, studies in Christian ethics have been critical to both types of ethics. Christian moral theorists have identified an alternative type of action-oriented ethics which is neither deontological nor utilitarian. As H.R. Niebuhr ${ }^{19}$ suggests, Christian ethics should start with identifying the context. It should first ask about 'what is going on', rather than 'what the rule is' or 'what the aim is.' Whilst a set of biblical rules or principles may be enough in a deontological approach, so is a theological vision such as that of the apocalyptic tradition in a utilitarian approach, Christian contextual ethics needs the help of 'worldly' sciences to grasp the actual moral problem it wants to respond to. In the case of the business context, the science of business morality would provide the description needed for identifying 'what is going on' in the field. In fact, business ethics learning could function not only descriptively but also normatively. At the normative side, a theological business ethics takes the form of an ethical discourse interacting philosophical and theological resources.

Practical Theology

The area of practical theology covers courses such as pastoral studies, mission, church development, worship, preaching, and Christian education. The understanding of business ethics is particularly important in respect of pastoral studies and mission. Pastoral studies prepare for a ministry of the church with the individuals and families as members of the community. Since pastoral cases are usually multidimensional, pastoral studies are inter-disciplinary in nature. Hence, courses in pastoral studies usually bring theology into interactions with psychology and cultural studies. The non-theological disciplines are needed to help the pastor identifying the problem being faced by the client. In the case of a church with many members working in the business sector, pastoral ministry cannot be adequate without an understanding of business

\footnotetext{
${ }^{18}$ Deon Rossouw, Developing Business Ethics as an Academic Field (Stellenbosch: Ben-Africa, 2004)

${ }^{19} \mathrm{H}$. Richard Niebuhr, The Responsible Self: An Essay in Christian Moral Philosophy (San Francisco: HarperSanFrancisco, 1963)
} 
ethics. Therefore, business ethics is worth considering as a partner of theology in pastoral studies. The inter-disciplinary nature of pastoral studies makes possible the inclusion of business ethics in the syllabus. Business ethics-informed pastoral studies would serve the need to assist people in dealing with personalmoral dilemma in the workplace, including questions related to spirituality such as those about the meaning of work, the idea of business as calling, human relationships within the firm and in the circle of the stakeholders, and decision making which is responsible economically as well as spiritually.

The second entry point for business ethics learning in the area of practical theology is the courses in mission. The relation of business to mission has been explained by Suki Bang as quoted by R. Paul Stevens. ${ }^{20}$ Among five possible models of business-mission relations described by Bang, ${ }^{21}$ the model of 'business as mission' implies the need of knowledge in business ethics. That model understands Christian mission as a participation in God's own mission which includes essential business activities. The concept of 'business as mission' has been introduced by a group of evangelical scholars met in '2004 Forum for World Evangelization' organized by the Lausanne Committee for World Evangelization. The group claims that the concept of 'business as mission' is holistic, in the sense that it covers a broad dimension of business including employment, economic resources, and economic development. 'Business as mission,' the group insists, opposes the practice of fake business set up simply for the strategic purpose of mission, such as to make possible visa issuance for the missionaries. Also, it is not about a business motivated by Christian faith but operated according to secular norms for individual interests. ${ }^{22}$ Hence, the concept of 'business as mission' is about doing business which is accountable both economically as well as ethically and, as such, complies with mission ideals. There is a strong impression that the evangelical group has developed its understanding of mission in a way that transforms the traditional concept of mission as simply conversion projects. The group tends to consider ethical business as a form of implicit mission. Using typically evangelical terms, the group is quite successful in reconciling the evangelical enthusiasm for faith proclamation and the ecumenical concern for social justice issues. The notion of 'business as mission' thus opposes theories contrasting Christian faith to business values, such as that of Gordon Pearson and Marc Lewis, as analyzed by Richard Higginson. In contrast to Max Weber's theory on Protestant ethic, both Pearson and Lewis consider Christian doctrines contradictory to business values. For them, to be economically viable, business must resist Christian ethical presuppositions which, they believe, are against

\footnotetext{
${ }^{20}$ R. Paul Stevens, Doing God's Business: Meaning and Motivation for the Marketplace (Grand Rapids/ Cambridge: Wm. B. Eerdmans, 2006) p. 80

${ }^{21}$ Bang suggests five models of business-mission relations: business and mission as two isolated activities, business for the purpose of mission, business as a platform for mission, mission carried out in business, and business as part of mission.
}

22 ‘Business as Mission’ Lausanne Occasional Paper, 59 (Lausanne Committee for World Evangelization, 2004) 
the ideas of success and productivity. ${ }^{23}$ The evangelical concept of 'business as mission,' is quite optimistic that a business can be mission-compliance and economically successful at once.

Contextual Theology and Religious Studies

Theological education in Asia has long developed theological concepts and practices which treat respectfully local cultural resources and non-Christian religions existing in the region. The endeavour results in a type of theology which is commonly called contextual theology. Since religions still work effectively in Asian societies, contextual theology needs the help of religious studies in exploring the context. While contextual theology uses theological language to interact with other theological perspectives and to speak to the faith community, religious studies are based on phenomenological premises and are more demanded to avoid preference to any particular faith community.

Among world religions, Islam seems to be the most ready one in promoting religious-based applied ethical economy. Although Christian ethical resources include practical guidance such as Roman Catholic social teaching and similar pastoral declarations issued by various Protestant denominations, they are not intended to be as systemic, comprehensive, and technical as Islamic economy. The same can be said in respect of the particular Protestant doctrines often related to what Max Weber calls 'Protestant work ethic.' D. Stephen Long points out that the relation of those doctrines to the modern economic life is by no means intentional. ${ }^{24}$ Islamic economy, on the contrary, has been practised in various business sectors including finance, retail, and tourism. Many large, multinational banks as well as national firms in several Asian countries have opened their shari'a-compliance units to accommodate business transactions using the Islamic economic principles. In the academic sphere, the idea of Islamic economy has attracted both economists and religious scholars, leading to its establishment as an academic field in business school as well as religious studies one. At the core of Islamic economics is the concern for ethically-responsible economic activities based on Islamic religious doctrines. ${ }^{25}$ Islamic economics is presented as an alternative for what Islamic economists call "conventional economics" which is capitalism. Islamic economists reject the claim that capitalist economics is value free and does not need an ethical consideration. Assessing the "mainstream economics" as individualistic, mercantilist, and utilitarian, they promote Islamic economy

\footnotetext{
${ }^{23}$ Richard Higginson, Questions of Business Life, pp. 21-24

${ }^{24}$ D. Stephen Long, Divine Economy: Theology and the Market (London/New York: Routledge, 2000), p. 25

${ }^{25}$ P3EI-UII, Ekonomi Islam. (Jakarta: RajaGrafindo Persada, 2008)
} 
claimed of integrating both positive and normative approaches. They go on to argue that the basic assumption of Islamic economy is that ethics must be prior to economic considerations. ${ }^{26}$

Asian Christian contextual theology should take account of Islamic economy as an important element of the contemporary situation worth responding. In this case, religious studies would be of help for identifying objectively the philosophical foundation and ethical significance of Islamic economy. The tradition of interreligious dialogue so much developed in Asian contextual theology should be extended to the area of business by making the phenomenon of Islamic economy as a starting point. Christian theology contains enough ethical resources worth dialoguing with Islamic teachings on economic life. Interacting with the idea of Islamic economy, Christian contextual theologians could become more aware of the potentials of Asian contextual theology to contribute to the ethical enquiries in the mezzo and micro levels of economic life.

\section{Key Topics}

Considering common ethical issues often dealt with in Asian firms as well as among Asian contextual theologians, and the variety of entry points available in contextual theological curricula, it is possible to select a number of those issues as key topics. The following topics are taken as samples only and thus by no means exhaustive.

The interaction of business and religion

Several 'secular' business ethicists have recognised the relationship between business and religion. For instance, George Chryssides and John Kaler mention religion as a source of moral theories worth exploring for developing business morality. ${ }^{27}$ Peter Davies singles out Christian theology as an important perspective affecting the area of business in the West.$^{28}$ In the area of sociology, scholars such as Robert Bellah ${ }^{29}$ and Peter Berger, ${ }^{30}$ who follow Max Weber's approach which highlights the cultural dimension of economic life,

\footnotetext{
${ }^{26}$ Ibid, pp. 24-26

${ }^{27}$ George D. Chryssides and John H.Kaler, An Introduction to Business Ethics (London etc: Chapman \& Hall, 1993), pp. 84-87

${ }^{28}$ Peter W.F. Davies, Current Issues in Business Ethics (London: Routledge, 1997), p.16

${ }^{29}$ Robert N. Bellah, Religi Tokugawa: Akar-akar Budaya Jepang (Jakarta: Gramedia, 1992)

${ }^{30}$ Peter L. Berger, 'Vice and Virtue in Economic Life' in Max Stackhouse, ed., Christian Social Ethics in a Global Era (Nashville: Abingdon Press, 1955)
} 
have also demonstrated the role of religion in shaping the economic attitude of particular societies. From the theological camp, scholars such as James Child Jr., ${ }^{31}$ Richard Higginson, ${ }^{32}$ and Max Stackhouse ${ }^{33}$ have called for more serious theological works responding to the issues of business. All those theologians insist that the interaction of business and religion in various ways is obvious, yet theology has been slow to respond to that reality. Child, in particular, notes at least five conditions which need to be overcome for theology to play a role in constructing business ethics. ${ }^{34}$ Firstly, there is a strong belief in (Western) Society that the kind of morality which is appropriate in public life is the one without any reference to religion. As Child suggests, this should be seen as a challenge to articulate theological moral commitments in a secular language. Secondly, there is a tendency to simplify a complex Christian ethical concept into a series of black and white principles. A comprehensive and open minded theological exploration is thus needed to avoid such a tendency. Thirdly, there remains a "dualistic assumption" separating spiritual life and business life. The challenge here is to promote the type of spirituality which is neither escapist nor isolationist, but rather committed to the transformation of the world. Fourthly, there is a common pessimism among the church elite regarding business morality. This implies the need of a contextual theology which considers the business world a context as worthy as the areas of politics and culture. Finally, from the side of the business world there is a tendency to consider the church unrealistic and therefore irrelevant. Such a presumption may not be based on updated information about what the church has learnt in terms of contextual theology. Nevertheless, it can be understood as a call to the church for making itself searchable more easily.

\section{Social responsibility}

Perhaps the most salient shared interest between business ethics and theology is in the issue of social responsibility. Christian theological resources concerning social responsibility are abundant. The Bible records prophecies, visions, teachings, poems, commandments, as well as advices which affirm the inseparability of faith from social responsibility. For instance, Jeremiah and Amos condemn the practices of worship without an awareness of social justice (Jr. 7:1-15; Am 5:21-27). In accord with the prophetic tradition of social responsibility, Jesus criticizes the law teachers and the Pharisees for promoting ritual ceremonies while neglecting the essentials which are "justice, compassion, and faithfulness" (Mt. 23:23).

\footnotetext{
31 James M. Childs Jr., Ethics in Business, Faith at Work (Minneapolis: Fortress Press, 1995)

32 Higginson, Questions of Business Life

${ }^{33}$ Stackhouse, "Christian Social Ethics in a Global Era"

${ }^{34}$ Childs, Ethics in Business, pp. 6-11
} 
Moreover, the emphasis in social responsibility is crucial in various church ethical documents, including those of the Roman Catholics and the Protestant ecumenical movement. In the practical level, major Christian denominations normally have a certain division dealing with social responsibility affairs.

Given such rich resources on social responsibility, Asian contextual theological teachings on economic issues tend to emphasize the social justice dimension. Such commitment to social justice is not only biblically grounded, but also contextually justified. For despite being a thriving and dynamic business environment, Asia still suffers from massive poverty in many parts of its countries. The economic growth achieved in those countries does not guarantee the elimination of poverty problems. The persistence of cities' slum areas; the inadequacy of housing, healthcare and education facilities; as well as human trafficking are among difficult poverty-related problems faced by many Asian countries.

Asian contextual theology's emphasis on social justice and its proclamation to be on the side of the poor, however, often arrive at the suspicion that the profit-oriented nature of business makes it inevitably socially irresponsible. The emergence of the idea of corporate social responsibility from the internal circle of the business world, however, should attract theologians to update their knowledge about the contemporary business context. In fact, the concept of corporate social responsibility is an attempt to integrate the tradition of corporate philanthropy with the idea of social empowerment promoted by civil society movements. At the heart of corporate social responsibility concept is the recognition that the corporation shares the responsibility to improve the living condition of the people. At the practical level, the planning and implementation of corporate social responsibility projects often involve not only the related corporation but also the government and groups of civil society. As such, the concept of corporate social responsibility can be seen as an advancement of the tradition of corporate philanthropy.

Theological teachings on economic life need to review their approach in order to contribute more constructively to the development of corporate social responsibility both at the conceptual and practical levels. The church's tradition of offering and giving as well as the experience with the church's diakonia projects make the church a competent partner of the corporation in term of corporate social responsibility. At the same time, theologians could learn from the concept of corporate social responsibility to seek its relevance for the context of a faith community, for instance to generate the idea of church social responsibility.

The balance of justice and entrepreneurship

Theological discourses pay much attention to the issue of justice. Despite the variety of perspectives and approaches, most major Christian traditions -Roman Catholic social teaching, Social Gospel, Liberation 
theology, ecumenical movement, and even recent evangelical tradition- demonstrate a serious concern for justice in economic life. Social theology tends to relate the problem of poverty to the issue of justice. On the other hand, business studies show the importance of entrepreneurship in helping the poor upgrade their economic performance. Despite Max Weber's theory, which relates the rise of modern capitalism to particular Protestant doctrines, few theologians have enough interest in entrepreneurship.

It is David Krueger who attempts to summon both the concern for justice and entrepreneurship in his theology of "productive justice." Krueger argues that in terms of justice, Christian ethicists tend to focus too much on the aspect of distribution while neglecting the aspect of production. As such, Christian ethicists deal more with the area of politics rather than that of economic life. Productive justice is about "qualities of character and ... structural enablements in society that are necessary for effective productive activity. ${ }^{\prime 35}$ Krueger's theory of productive justice balances the concern for human rights protection as well as the appreciation and encouragement for productivity.

Family business and familism

The role of the family in business is one of the most discussed topics in respect of Asian business environment. ${ }^{36}$ The term ' familism' refers to the centrality of the family both in the institutional structure of the firm and its moral resources. ${ }^{37}$ The impact of familism in business is ambivalent. On the one hand, familism contributes to the efficiency and, thus, competitiveness of the firm by reducing the costs of supervision and bureaucracy given the high trust it embeds. Commitment to the family's moral preferences becomes crucial particularly where rule of law implementation is often uncertain as is the case in many countries of emerging and developing economies. Moreover, since a family-centred enterprise is a community of trust, the nature of work relations is more personal than contractual. This provides reasoning for the flexibility required in the fast changing business context. On the other hand, over dependence on the family can limit the growth of the firm, since an upsizing business often needs leadership, the extent of trust, and cultural values beyond what a family could provide. Family-centred

\footnotetext{
${ }^{35}$ Krueger, The Business Corporation, p. 44

${ }^{36}$ See, for instance: Chin Fei Goh, Amran Rasli, Owee Kowang Tan, and Sang Long Choi, 'Socioemotional Wealth and Firms' Control: Evidence from Malaysian Chinese Owned Companies' Gadjah Mada International Journal of Business. 17:3 (2015), 259-277, at 260; also: Akira Suehiro and Natenapha Wailerdsak, 'Family Business in Thailand: Its Management, Governance, and Future Challenges', ASEAN Economic Bulletin, 21:1 (2004), 81-93

37 Regarding familism, see: Yahya Wijaya, 'The Prospect of Familism in the Global Era: A Study on the Recent Development of the Ethnic-Chinese Business, with Particular Attention to the Indonesian Context' Journal of Business Ethics, 79 (2008), pp. 311-317, doi 10.1007/s.10551-007-9399-z
} 
firms are also easily affected by conflicts and frictions occurred in the family as well as the financial difficulty of the family as a consequence of its members' lifestyle.

Theological education pays much attention to family issues. Churches consider the family a building block of the congregation and society. For that reason many churches offer family worship service and develop house groups of bible study. Popular Christian rites such as baptism and wedding service are family-based by nature. Moreover, the Bible picks several families as contexts of its story of salvation and, as such, depicts human beings as basically one big family.

However, biblical accounts concerning family matters would not make them sufficient to support familism. In fact, the biblical depiction of the importance of the family is often presented in stories critical to the practices which overrate the family. Family stories in the Bible are not only about love and faithfulness, but also about betrayal, negligence, adultery, and even rape and murder. One obvious example of the biblical criticism of familism is the gospel story demonstrating Jesus' concept of family which transcends the boundary of the biological family (Mt. 12:46-50). Hence, a Christian theology of family could make a good reference for dealing with the problem of familism in business. At the same time, theology could learn from business studies' exploration regarding familism in business to respond to the tendency toward exclusivity and favouritism which is often found within the church.

Leadership and management

Leadership and management are crucial topics both in business studies and theology. The issue of leadership styles and the challenge to transform leadership-ownership relations are often singled out in studies concerning the characteristics of Asian business in relation to the global market. ${ }^{38}$ In business studies, many have discussed the relation of the concept of leadership and management to religion. Among them are Samford University's business studies scholars, Robert Service and Charles Carson, who argue that modern management and leadership are products of the culture of democracy and individuality which are linked to Protestant Reformation. Contextual management and leadership learning, they suggest, should pay attention to the aspects of history, culture, as well as methods of decision making, which all contain strong religious element. ${ }^{39}$ Service and Carson's opinion may be debatable, but at least

\footnotetext{
${ }^{38}$ For instance: Akira Suehiro and Natenapha Wailerdsak, 'Family Business in Thailand', 90-92

${ }^{39}$ Robert W (Bill) Service and Charles M Carson, 'Management and Leadership: Religion the "Mother of All Context"' Interbeing, 3:1 (2009), 37-43, at 39
} 
they draw attention to the broad context of leadership and management which includes the contexts of religion and culture, the contexts which theologians deal with on daily basis.

Remarkable references concerning leadership and management can be found in the Bible, church history, as well as theology of church organization. They have been made the basis of the study of church leadership and management which, in the theoretical domain, learns things from the business world. Hence, business leadership and management are not too unknown in theological studies, particularly the area of church development or church growth. In fact, business studies and theology have shared the same language in depicting particular concepts of leadership and management, such as that of servant leadership. Although the business studies' theory of servant leadership may not be related to any theological resource, theology has much to share in the philosophical exploration of such a theory.

\section{Conclusion}

I have been arguing that today's pastors and church leaders should be equipped with knowledge in business ethics in order for them to respond adequately to the challenges faced by their community members who work in the business sector. However, theological education in Asia, particularly with the background of Protestant traditions, has not yet paid as much attention to business ethics learning as it has to the studies of personal and broader social ethics. Yet business ethics can be compatibly placed in theological curricula. Areas of theological study, including biblical studies, systematic theology, practical theology, as well as contextual theology and religious studies, can be fitting entry points for theological business ethics learning. Key topics of theological business ethics can be developed from issues already discussed in both theological circle and that of business studies. Those include the interaction of business and religion, the balance of justice and entrepreneurship, social justice, family business and familism, as well as leadership and management. 